\title{
Breast Cancer is A Serious Disease for Women
}

\author{
Adnan W Al-Mudhafr* \\ Department of Food Science, University of Kufa, Iraq
}

Submission: January 10, 2019 ; Published: January 18, 2019

*Corresponding author: Adnan W Al-Mudhafr, Department of Food Science, University of Kufa, Iraq

\section{Opinion}

It is one of the most common cancers in women, the second leading cause of death in women, after lung cancer. Progress in screening and treatment has significantly improved survival rates since 1989, awareness of symptoms and the need for screening are important ways to reduce the risk of disease, breast cancer can affect men as well.

\section{What is breast cancer?}

After puberty, the woman's breasts consist of fat, connective tissue, thousands of lobules, and small glands that produce milk for breastfeeding. When cancer occurs, the cells of the body multiply uncontrollably, causing cancer.

\section{Symptoms of breast cancer}

Usually the initial symptoms of breast cancer are the presence of thick tissue in the breast, or a lump in the breast or in the armpit Other symptoms include:

a) Pain in the armpit or breast that does not change with the menstrual cycle

b) The redness of the skin of the breast and its transformation into orange color

c) The appearance of a rash around or on one of the nipples

d) The discharge of the nipple may contain blood

e) The nipple is sunken or inverted

f) Change the size or shape of the breast

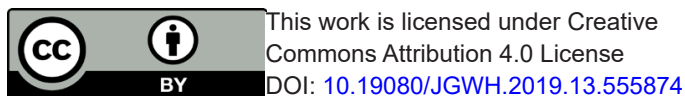

g) Peeling or falling skin on the breast or nipple

h) Most of the lumps that appear are not cancerous, but should be checked by a healthcare professional immediately

\section{Factors that increase the chances of breast cancer}

Breast cancer usually begins in the inner lining of the milk ducts or lobules that supply it with milk and can spread to other parts of the body. The exact cause is still unclear, but some risk factors make it more likely.

a) Age where risk increases with age for breast cancer.

b) Genetics Genetic factors influence cancer because the disease's transgenic genes can be inherited.

c) Women who have breast cancer are more likely to be infected again, compared to those who do not have a history of the disease, such as having some benign or non-cancerous species increases the chance of developing cancer later.

d) Exposure to estrogen for a longer period increases the risk of breast cancer.

e) Obesity or postmenopausal obesity in women may have a greater risk of breast cancer, possibly due to elevated levels of estrogen.

f) Radiation therapy increases the risk of breast cancer later in life.

g) Hormone replacement therapy and oral contraceptives increase breast cancer, due to increased levels of estrogen.

Your next submission with Juniper Publishers will reach you the below assets

- Quality Editorial service

- Swift Peer Review

- Reprints availability

- E-prints Service

- Manuscript Podcast for convenient understanding

- Global attainment for your research

- Manuscript accessibility in different formats

( Pdf, E-pub, Full Text, Audio)

- Unceasing customer service

Track the below URL for one-step submission https://juniperpublishers.com/online-submission.php 